\title{
The influence of $\mathrm{MgSO}_{4}$, race and mating pattern on the concentration of some lipids in rabbit organs (short communication)
}

\begin{abstract}
Summary
The study was performed on New Zealand White breed and Black Bay breed rabbits. The 70 - and 140 - day old inbred and random rabbits were killed in the classical method by the breaking of the spinal cord (strong blow). The 180-day old individuals in the first subgroup were killed similary by the breaking of the spinal cord, and in the second subgroup by injection of $2 \mathrm{ml} / \mathrm{kg}$ b.w. $10 \%$ solution $\mathrm{MgSO}_{4}$ to their ear vein. The liver, kidney muscle and blood serum of the 70-day old inbred rabbits showed lower level of total lipids and triglycerides in comparison with the random mated animals. $\mathrm{MgSO}_{4}$ administration decreased the level of total lipids in the liver and kidney of random $\mathrm{BB}$ individuals. $\mathrm{MgSO}_{4}$ injection decreased the triglyceride concentration in the liver of random rabbits and in the muscle, blood serum of inbred New Zealand animals. It decreased the level of cholesterol in the kidney and muscle of NZ rabbits and in the blood serum of the random and inbred BB animals.
\end{abstract}

Key Words: rabbits, inbred, magnesium $\left(\mathrm{MgSO}_{4}\right)$, triglycerides, cholesterol, total lipids

\section{Zusammenfassung}

Titel der Arbeit: Einfluß von $\mathbf{M g S O}_{4}$, Rasse und Zuchtverfahren auf den Gehalt einiger Lipide in Kaninchenorganen (Kurzmitteilung)

Der Gehalt einiger Lipide in Leber, Niere, Muskel und Blutserum von 70, 140 und 180 Tage alten Kaninchen der Rassen „Weiße Neuseelănder" (NZ) und „Black Bay“(BB) wurden untersucht. Jungere ingezulchtete Tiere hatten in der Leber, der Niere und im Muskel ein niedrigeres Niveau an Gesamtlipiden und Triglyzeriden als nicht ingezllchtete. Eine $\mathrm{MgSO}_{4}$-Injektion in die Ohrvene bewirkte eine Verminderung der Gesamtlipidkonzentration in der Niere und Leber der nicht ingezlichteten BB-Tiere. Die gleiche Injektion bewirkte eine Verminderung der Triglyzerinkonzentration in der Leber der nicht ingezlichteten und im Muskel und Blutserum der ingezilchteten NZ-Tiere. Ebenfalls kam es zu einer Senkung des Cholesterinspiegels in Leber und Muskel der NZ-und im Blutserum beider BB-Tiergruppen.

Schlusselwörter: Kaninchen, Inzucht, Magnesiumsulfat, Triglyzeride, Cholesterin, Gesamtlipide

\section{Introduction}

Among the contemporary applied methods of the slaughter of domestic animals without the stress reaction there are the pharmacological means too. They consist of injecting specific substances that have the tranquilizing action on the behavior of the animal. Magnesium sulfate belongs to these substances (GARBULIÑSKI, 1984; FITKO et al., 1976). In our paper we have taken into account the influence of $\mathrm{MgSO}_{4}$ on concentration of some lipids in the blood serum, liver, kidney and muscle of inbred and random mated rabbits. 


\section{Material and Methods}

The study was performed on rabbits from the Agricultural University in Cracow of the New Zealand White breed and Black Bay breed. Thirty animals were 70 days old, thirty 140 days old and 120 animals were 180 days old. All animals weighed 2.0 - 2.5 $\mathrm{kg}$ and were fed standard industrial granulated fodder for rabbits ( $16 \%$ of protein) and carrots. The access to water was available in their cages. In the farm the ventiled hall was $18^{\circ}-22^{\circ} \mathrm{C}$ and 50:50 dark/light. The animals were mated in an inbred (brother $\mathrm{x}$ sister, father $\mathrm{x}$ daughter and mother $\mathrm{x}$ son) and random (outbred) way. The random animals comprised the control groups. All animals exhibited very good physical conditions and remained under a good veterinary care.

The 70 - and 140 - day old rabbits were killed by breaking their spinal cord with strong blow [classical method]. The 180- day old inviduals in the first subgroup were killed by a similar method while in the second subgroup by injection of $2 \mathrm{ml} / \mathrm{kg} \mathrm{b.w.} 10 \%$ solution of $\mathrm{MgSO}_{4}$ to the ear vein.

Immediately after the slaughter $\left(9^{\circ \circ}-10^{\circ 0}\right.$ a.m. $)$, the slices of liver, kidney and muscle [musculus longissimus dorsi on the last rib level] were subjected to perfusion with a cooled solution of $0.9 \% \mathrm{NaCl}$, minced and homogenized in $0.1 \mathrm{M}$ phosphate buffer at $\mathrm{pH}-7.4$ at the temperature $+4^{0}$ in a teflon homogenizer at 200 rot. $/ \mathrm{min}$. After centrifuge, the concentration of total lipids [ $\mathrm{mg} / \mathrm{g}$ of fresh tissue], cholesterol and triglycerides [umol/g of fresh tissue] was determined in supernatants. These compounds were also determined in the blood serum $(\mathrm{mM} / \mathrm{l})$, total lipids in $\mathrm{g} / \mathrm{l}$. The biochemical tests „Lachema” (Slovakia) and spectrophotometer „Specol” were used. The obtained results were analysed by the Student's test.

\section{Results}

From Table 1 we can see that there exist lower levels of the total lipids and triglycerides in all organs of the 70-day old inbred New Zealand rabbits in comparison with the random mated animals. The differences in total lipids were significant in the kidney $(73.8 \%$ ) and blood serum $(62.2 \%)$, in triglycerydes $77.6 \%$ and $68.5 \%$ respectively. In the 140-day old animals were the significant differences in kidney, $81.7 \%$ for lipids and $81.1 \%$ for triglycerides. In the 180 - day old individuals the significant differences were found for total lipids in blood serum only (75.0\%).

Table 2 informs that $\mathrm{MgSO}_{4}$ injection caused decreases in triglyceride concentration in the liver of random animals $(84.2 \%)$, in the muscle $(84.3 \%)$ and blood serum $(82.3$ $\%)$ of inbred animals of the New Zealand race and in the muscle of the random Black Bay group (82.0\% of control value).

Table 3 shows that $\mathrm{MgSO}_{4}$ injection influenced significantly the decrease of cholesterol level in kidney of the random (83.0\%) and in the muscle of the inbred New Zealand animals $(85.9 \%)$. In the Black Bay race, these statistically confirmed differences were found in the blood serum $(85.7 \%$ and $81.3 \%)$.

Similar changes can be seen in Table 4 . The concentration of total lipids decreased significantly in the liver (77.4\%) and the kidney (81.5\%) of the random mated Black 
Arch. Tierz 43 (2000) 1

\section{Bay animals.}

Table 1

The level $\left(\bar{x} \pm S_{d}\right)$ and percent of total lipids ( $\mathrm{mg} / \mathrm{g}$ )and triglycerides (umol/g) in the liver, kidney, muscle and in blood serum of inbred and random New Zealand breed rabbits aged 70, 140, 180 days; [ $\mathrm{n}$ in each subgroup $=15$ ] (Gesamtlipid- und Triglyzerinniveau in Leber, Niere, Muskel und Blutserum bei unterschiedlichem Alter der Tiere in Abhăngigkeit vom Zuchtverfahren)

\begin{tabular}{|c|c|c|c|c|c|c|c|c|c|}
\hline \multirow{2}{*}{$\begin{array}{c}\text { Age } \\
\text { (days) }\end{array}$} & \multirow[t]{2}{*}{ Mating } & \multicolumn{4}{|c|}{ Total lipids } & \multicolumn{4}{|c|}{ Triglycerides } \\
\hline & & Liver & Kidney & Muscle & $\begin{array}{c}\text { Blood } \\
\text { serum } \\
(\mathrm{g} / \mathrm{l})\end{array}$ & Liver & Kidney & Muscle & $\begin{array}{l}\text { Blood } \\
\text { serum } \\
(\mathrm{mM} / \mathrm{l})\end{array}$ \\
\hline & $\begin{array}{c}\text { Random } \\
\%\end{array}$ & $\begin{array}{c}72.4 \pm 20.5 \\
100\end{array}$ & 100 & 100 & $\begin{array}{c}3.7 \pm 0.75^{2} \\
100\end{array}$ & $\begin{array}{c}14.4 \pm 8.2 \\
100\end{array}$ & $\begin{array}{c}16.5 \pm 3.2^{3} \\
100\end{array}$ & $\begin{array}{c}15.4 \pm 3.8 \\
100\end{array}$ & $\begin{array}{c}2.7 \pm 0.6^{4} \\
100\end{array}$ \\
\hline 70 & Inbred & $\begin{array}{c}71.3 \pm 39.8 \\
98.5\end{array}$ & $\begin{array}{c}48.0 \pm 22.7^{1} \\
73.8\end{array}$ & $\begin{array}{c}36.6 \pm 8.4 \\
94.1\end{array}$ & $\begin{array}{c}2.3 \pm 0.9^{2} \\
62.2\end{array}$ & $\begin{array}{c}13.4 \pm 4.2 \\
93.1\end{array}$ & $\begin{array}{c}12.8 \pm 4.5^{3} \\
77.6\end{array}$ & $\begin{array}{c}15.2 \pm 4.1 \\
98.7\end{array}$ & $\begin{array}{c}1.9 \pm 0,7^{4} \\
68.5\end{array}$ \\
\hline & $\begin{array}{c}\text { Random } \\
\%\end{array}$ & $\begin{array}{c}101.3 \pm 68.1 \\
100\end{array}$ & $\begin{array}{c}99.7 \pm 58.4^{5} \\
100\end{array}$ & $\begin{array}{c}92.9 \pm 55.8 \\
100\end{array}$ & & $\begin{array}{c}61.3 \pm 50.1 \\
100\end{array}$ & $\begin{array}{c}59.8 \pm 29.8^{3} \\
100\end{array}$ & $\begin{array}{c}29.7 \pm 26.0 \\
100\end{array}$ & $\begin{array}{c}4.3 \pm 1.7 \\
100\end{array}$ \\
\hline 140 & $\begin{array}{c}\text { Inbred } \\
\%\end{array}$ & $\begin{array}{c}106.8 \pm 83.7 \\
105.4\end{array}$ & $\begin{array}{c}81.5 \pm 46.2^{5} \\
81.7\end{array}$ & $\begin{array}{c}102.7 \pm 58.5 \\
110.5\end{array}$ & $\begin{array}{c}4.3 \pm 1.3 \\
110.2\end{array}$ & $\begin{array}{c}67.3 \pm 27.9 \\
109.8\end{array}$ & $\begin{array}{c}48.5 \pm 38.1^{6} \\
81.1\end{array}$ & $\begin{array}{c}30.7 \pm 23.6 \\
103.4\end{array}$ & $\begin{array}{c}4.1 \pm 2.1 \\
95.3\end{array}$ \\
\hline & $\begin{array}{c}\text { Random } \\
\%\end{array}$ & $\begin{array}{c}20.6 \pm 3.5 \\
100\end{array}$ & $\begin{array}{c}23.7 \pm 6.0 \\
100\end{array}$ & $\begin{array}{c}18.7 \pm 2.9 \\
100\end{array}$ & $\begin{array}{c}4.0 \pm 1.8^{T} \\
100\end{array}$ & $\begin{array}{c}20.3 \pm 3.4 \\
100\end{array}$ & $\begin{array}{c}19.0 \pm 5.7 \\
100\end{array}$ & $\begin{array}{c}7.5 \pm 1.6 \\
100\end{array}$ & $\begin{array}{c}1.8 \pm 0.4 \\
100\end{array}$ \\
\hline 180 & $\begin{array}{c}\text { Inbred } \\
\%\end{array}$ & $\begin{array}{c}22.8 \pm 4.9 \\
110.7\end{array}$ & $\begin{array}{c}19.5 \pm 4.0 \\
82.3\end{array}$ & $\begin{array}{c}17.3 \pm 4.1 \\
92.5\end{array}$ & $\begin{array}{c}3.0 \pm 1.7^{7} \\
75.0\end{array}$ & $\begin{array}{c}22.7 \pm 5.8 \\
111.8\end{array}$ & $\begin{array}{c}22.6 \pm 6.0 \\
118.9\end{array}$ & $\begin{array}{c}8.3 \pm 2.0 \\
110.6\end{array}$ & $\begin{array}{c}1.7 \pm 0.3 \\
94.4\end{array}$ \\
\hline
\end{tabular}

$1-1 ; 2-2 ; 3-3 \ldots . .6 \cdot 6 ; 7-7$ - the differences statistically confirmed, $p<0.05 ; p<0.01$

Table 2

The level of triglycerides $\left(\bar{x} \pm S_{d}\right)$ in the liver, kidney, muscle (umol/g) and blood serum (mM/l) of 180 - day old inbred and random New Zealand and Black Bay breed rabbits, killed classically and by $10 \% \mathrm{MgSO}_{4}$ injection; $\left[\mathrm{n}\right.$ in each subgroup $=15$ ] (Triglyzerinniveau untersuchter Organe 180 Tage alter Tiere nach $\mathrm{MgSO}_{4}$ Injektion bei unterschiedlichem Alter der Tiere in Abhăngigkeit vom Zuchtverfahren)

\begin{tabular}{|c|c|c|c|c|c|c|c|c|c|}
\hline \multirow[b]{2}{*}{ Mating } & \multirow[b]{2}{*}{ Slaughter } & \multicolumn{4}{|c|}{ New Zealand } & \multicolumn{4}{|c|}{ Black Bay } \\
\hline & & Liver & Kidney & Muscle & $\begin{array}{l}\text { Blood } \\
\text { serum }\end{array}$ & Liver & Kidney & Muscle & $\begin{array}{l}\text { Blood } \\
\text { serum }\end{array}$ \\
\hline & $\begin{array}{l}\text { Classic } \\
\text { method }\end{array}$ & $\begin{array}{c}20.3 \pm 3.4^{1} \\
100\end{array}$ & $\begin{array}{c}19.0 \pm 5.7 \\
100\end{array}$ & $\begin{array}{c}7.5 \pm 1.6 \\
100\end{array}$ & $\begin{array}{c}1.8 \pm 0.4 \\
100\end{array}$ & $\begin{array}{c}18.5 \pm 5.9 \\
100\end{array}$ & $\begin{array}{c}22.5 \pm 4.6 \\
100\end{array}$ & $\begin{array}{c}10.0 \pm 3.0^{2} \\
100\end{array}$ & $\begin{array}{c}1.7 \pm 0.6 \\
100\end{array}$ \\
\hline $\begin{array}{c}\text { Random } \\
\%\end{array}$ & $\mathrm{MgSO}_{4}$ & $\begin{array}{l}17.1 \\
\pm 3.4^{1}\end{array}$ & $\begin{array}{c}18.6 \pm 1.8 \\
97.8\end{array}$ & $\begin{array}{c}7.2 \pm 2.0 \\
98.6\end{array}$ & $\begin{array}{c}1.7 \pm 0.3 \\
94.4\end{array}$ & $\begin{array}{c}16.9 \pm 3.8 \\
91.3\end{array}$ & $\begin{array}{c}19.6 \pm 7.7 \\
87.0\end{array}$ & $\begin{array}{c}8.2 \pm 2.3^{2} \\
82.0\end{array}$ & $\begin{array}{c}1.6 \pm 0.3 \\
94.1\end{array}$ \\
\hline & $\begin{array}{l}\text { Classic } \\
\text { method }\end{array}$ & $\begin{array}{c}22.7 \pm 5.8 \\
100\end{array}$ & $\begin{array}{c}22.6 \pm 6.0 \\
100\end{array}$ & $\begin{array}{c}8.3 \pm 2.0^{5} \\
100\end{array}$ & $\begin{array}{c}1.7 \pm 0.3^{4} \\
100\end{array}$ & $\begin{array}{c}20.8 \pm 6.0 \\
100\end{array}$ & $\begin{array}{c}21.7 \pm 5.2 \\
100\end{array}$ & $\begin{array}{c}8.8 \pm 2.6 \\
100\end{array}$ & $\begin{array}{c}1.7 \pm 0.4 \\
100\end{array}$ \\
\hline $\begin{array}{c}\text { Inbred } \\
\%\end{array}$ & $\mathrm{MgSO}_{4}$ & $\begin{array}{c}20.9 \pm 5.8 \\
92.1\end{array}$ & $\begin{array}{c}19.5 \pm 4.7 \\
86.3\end{array}$ & $\begin{array}{c}7.0 \pm 3.5^{3} \\
84.3\end{array}$ & $\begin{array}{c}1.4 \pm 0.3^{4} \\
82.3\end{array}$ & $\begin{array}{c}21.2 \pm 6.7 \\
102.0\end{array}$ & $\begin{array}{c}18.7 \pm 5.5 \\
86.2\end{array}$ & $\begin{array}{c}7.7 \pm 3.5 \\
87.5\end{array}$ & $\begin{array}{c}1.5 \pm 0.3 \\
88.2\end{array}$ \\
\hline
\end{tabular}

$1-1 ; 2-2 ; 3-3$ and $4-4-$ the differences statistically confirmed, $p<0.01$;

\section{Discussion}

It is known that magnesium takes part in almost all important biochemical pathways. It diminishes excitability of nervous cells and fibres, accelerates the processes of protein biosynthesis, stabilizes heart rate. It has anti - stress properties too (ALTURA and 
Table 3

The level of cholesterol $\left(\overline{\mathrm{x}} \pm \mathrm{S}_{\mathrm{d}}\right)$ in the liver, kidney, muscle (umol/g) and blood serum $(\mathrm{mM} / \mathrm{l})$ of 180 - day old inbred and random New Zealand and Black Bay breed rabbits, killed clasically and by $10 \% \mathrm{MgSO}_{4}$ injection; [ $\mathrm{n}$ in each subgroup $=15$ ] (Cholesterinniveau untersuchter Organe 180 Tage alter Tiere nach $\mathrm{MgSO}_{4}$-Injektion bei unterschiedlichem Alter der Tiere in Abhängigkeit vom Zuchtverfahren)

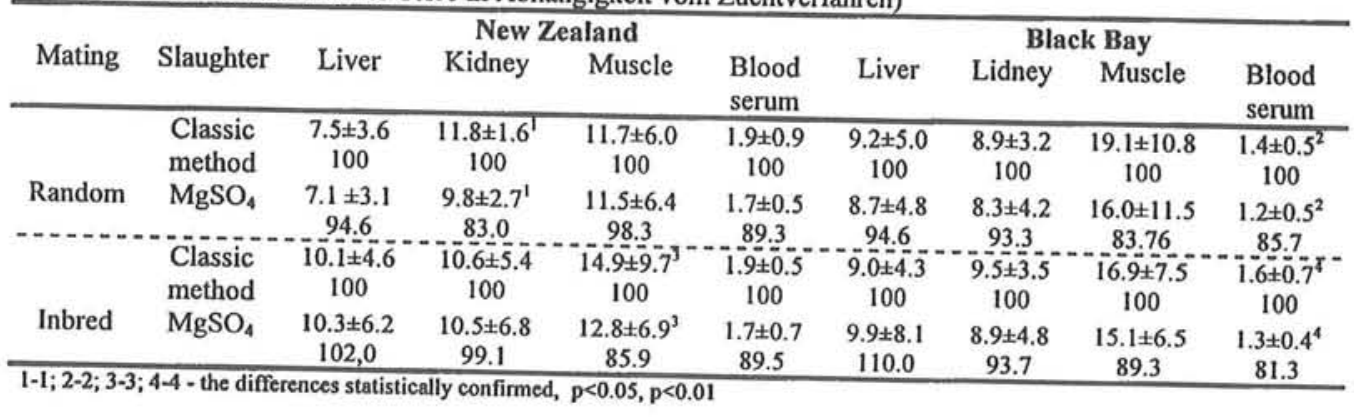

\section{Table 4}

The level of total lipids $\left(\bar{x} \pm S_{d}\right)$ in the liver, kidney, muscle $(\mathrm{mg} / \mathrm{g})$ and blood serum $(\mathrm{g} / \mathrm{l})$ of 180 - day old inbred and random New Zealand and Black Bay breed rabbits, killed classically and by $10 \% \mathrm{MgSO}_{4}$ injection; $\left[\mathrm{n}\right.$ in each subgroup $=15$ ] (Gesamtlipidniveau untersuchter Organe 180 Tage alter Tiere nach $\mathrm{MgSO}_{4}$-Injektion bei unterschiedlichem Alter der Tiere in Abhängigkeit vom Zuchtverfahren)

\begin{tabular}{|c|c|c|c|c|c|c|c|c|c|}
\hline \multirow[b]{2}{*}{ Mating } & \multirow[b]{2}{*}{ Slaughter } & \multicolumn{4}{|c|}{ New Zealand } & \multicolumn{4}{|c|}{ Black Bay } \\
\hline & & Liver & Kidney & Muscle & $\begin{array}{l}\text { Blood } \\
\text { serum }\end{array}$ & Liver & Kidney & Muscle & $\begin{array}{l}\text { Blood } \\
\text { serum }\end{array}$ \\
\hline \multirow[b]{3}{*}{ Random } & Classic & $20.6 \pm 3.5$ & $23.7 \pm 6.0$ & $18.7 \pm 2.9$ & $4.03 \pm 1.8$ & $19.9 \pm 3.8^{1}$ & $10.3 \pm 3.5^{2}$ & $9.6 \pm 2.9$ & $2.0 \pm 09$ \\
\hline & method & 100 & 100 & 100 & 100 & 100 & 100 & 100 & 100 \\
\hline & $\mathrm{MgSO}_{4}$ & $18.3 \pm 2.6$ & $22.2 \pm 4.8$ & $17.9 \pm 2.5$ & $3.9 \pm 0.3$ & $15.4 \pm 4.8^{1}$ & $8.4 \pm 2.6^{2}$ & $8.7 \pm 2.7$ & $1.7 \pm 0.5$ \\
\hline & & 88.8 & 93.6 & 95.7 & 96.8 & 77.4 & 81.5 & 90.6 & 85.0 \\
\hline \multirow{4}{*}{ Inbred } & Classic & $22.8 \pm 4.9$ & $19.5 \pm 4.0$ & $17.3 \pm 4.1$ & $3.03 \pm 1.7$ & $21.3 \pm 5.8$ & $15.3 \pm 3.4$ & $9.3 \pm 3.6$ & $1.9 \pm 0.7$ \\
\hline & method & 100 & 100 & 100 & 100 & 100 & 100 & 100 & 100 \\
\hline & $\mathrm{MgSO}_{4}$ & $21.3 \pm 3.8$ & $17.3 \pm 3.4$ & $15.2 \pm 3.2$ & $3.1 \pm 1.3$ & $20.8 \pm 4.9$ & $13.9 \pm 5.6$ & $10.3 \pm 5.1$ & $1.8 \pm 0.3$ \\
\hline & & 93.4 & 88.7 & 87.9 & 102.3 & 97.6 & 90.8 & 110.7 & 94.7 \\
\hline
\end{tabular}

\section{ALTURA, 1981; AKAZAWA et al., 1997; FONTENOT et al, 1983; CHUTKOW, 1980; YAN et al., 1997).}

The mobilization of magnesium in stress states is part of the defense mechanism of tissue (CLASSEN, 1981). Lipolise requires the presence of magnesium too. The lack of magnesium increases the concentration of triglycerides in the blood serum (ALTURA et al., 1996; NIEMALA et al., 1997; VORMANN et al., 1983; RAYSSIGNIER, 1981; RAYSSIGNIER et al., 1981;). The injection of $\mathrm{MgSO}_{4}$ to the veins of animal represses the secretion of acetylocholin or noradrenalin in the nerve endings.

We have found that in 10 cases the $\mathrm{MgSO}_{4}$ injection decreased significantly the concentration of studied lipids in 180 - day old inbred and random animals.

It is known that the catecholamines increase the rate of fat mobilization in the connective tissues by lipolise. It is possible to suggest that injection of $\mathrm{MgSO}_{4}$ blocks partly the adrenal cortex and the action of hypothalamus, and thus counteracts the development of shock. In our experiment the animals injected with $10 \% \mathrm{MgSO}_{4}$ 
solution revealed a lower stress reaction in comparison with the normally killed rabbits. They had lower levels of estimated biochemical indicators. We can suppose that $\mathrm{MgSO}_{4}$ is the factor which decreases the depth of stress reaction before the slaughter of animals.

It seems that the level of total lipids and triglycerides in the inbred rabbits was somewhat lower than in the random mated animals. It is known that at the animal farms inbred mating is avoided because the individuals from such matching produce less desirable traits. It is a main question of breeding whether inbred animals really have lower energy requirement, and lower rate of metabolic reactions in their organs ?

\section{Acknowledgment}

The authors would like to thank to Professor Zbigniew Staliñski and dr. Jozef Bieniek (Agricultural University in Cracow) for the experiment animals and the cordial atmosphere during the laboratory work.

\section{References}

ALTURA, B.T.; ALTURA, B.M.:

Role of $\mathrm{Mg}$ ions in contractility of blood vessels and skeletal muscles. Magnesium Bull. 3 (1981), 102114

ALTURA, B.M.; GEBREWOLD, A.; ALTURA, B.T.; BRAUTBAR, N.:

Magnesium depletion impairs myocardial carbohydrate and lipid metabolism in cardiac bioenergetics and raises myocardial calcium in vivo: Relationship to etiology of cardiac diseases. Biochem. Mol. Biol. Int., 1996, 40 (1996), 1183-1191

AKAZAWA, S.; SHIMIZU, R.; NAKAIGAWA, Y.; ISHII, R.; IKENO, S.; YAMATO, R.: Effects of magnesium sulfate on arterioventricular conduction times and surface electrocardiogram in dogs anaesthetized with sevoflurane. Brit. J. Anaesth. 78 (1997), 75-81

CHUTKOW, J.G.:

The neurophysiological function of $\mathrm{Mg}$ : effects of $\mathrm{Mg}$ excess and deficit. In: „Magnesium in health and disease", Spectrum Press Publishing, New York. 1980, 713-752

CLASSEN, H.G.: Stress reactions modified by $\mathrm{Mg}$ status. Magnesium Bull. 3 (1981), 148-154

FITKO, R.; WACHOWIAK, J.; WOJTATOWICZ, Z.:

The stress states in the animals. (Polish Language). Publication Bureau 'Chemistry', Warszawa, 1976

FONTENOT, J.P.; BUNCE, G.E.; WEBB, JR. K.E.; ALLEN, V.G.: Role of $\mathrm{Mg}$ in animal nutrition. John Lee Prat Animal Nutrition Program, Blacksburg, 1983

GARBULIÑSKI T.: Veterinary Pharmocology. (Polish Language). State Agricultural and Forest Publishing House, Warszawa, 1984

NIEMALA, J.E.; CSAKO, G.; BUI, M.N.; ELIN, R.J.: Gender - specific correlation of platelet ionized magnesium and serum low - density lipoprotein cholesterol concentrations in apparently healthy subjects. J. Lab. Clin. Med. 129 (1997), 89-97

RAYSSIGNIER, Y.:

$\mathrm{Mg}$ and lipids interrelationships in the pathenogenesis of vascilar diseases. Magnesium - Bull. 3 (1981), 165-177

RAYSSIGNIER, Y.; GUEUX, E.; WEISER, D.:

Effect of Mg deficiency on lipid metabolism in rats fed a high carbohydrate diet. J. Nutr. 111 (1981), 1876-1883

VORMANN, J.; FÖRSTER, R.; GÜNTHER, T.; EBEL, H.:

Lipolysis - induced Mg uptake into fat cells. Magnesium Bull. 5 (1983), 39-41 
YAN, L.Y.; PRENTICE, A.; DOBBA, B.; JARJOU, L.M.A.; STIRLING, D.M.; FAIRWEATHER, S.:

The effect of long-term calcium supplementation on indices of iron, zinc and magnesium status in lactating Gambian women. Br. J. Nut: 76 (1997), 821-833

Received: 19.03 .1999

Accepted: 12.11 .1999

Authors' addresses

Dr. JOLANTA KLUSEK, Dr. GRAŻYNA ŚWIDERSKA-KOŁACZ

Department of Genetics

Pedagogical University in Kielce

Konopnickiej 15

25-406 Kielce

Poland

Prof. Dr. ADAM KOŁĄTAJ

Institute of Animal Genetics and Breeding

Polish Academy of Sciences, Jastrzębiec

05-551 Mroków

Poland 